\title{
Nutritional Properties of Some BRRI HYV Rice in Bangladesh
}

\author{
Habibul Bari Shozib ${ }^{*}$, Saima Jahan ${ }^{2}$, Muhammad Zakir Sultan ${ }^{3}$, Samsul Alam ${ }^{4}$, Suman Chandra Das ${ }^{4}$, Rifat Bin Amin ${ }^{4}$, Mahedi Hasan ${ }^{4}$ and Muhammad Ali
} Siddiquee ${ }^{1}$

${ }^{1}$ Grain Quality and Nutrition Division, Bangladesh Rice Research Institute (BRRI), Gazipur-1701, Bangladesh

${ }^{2}$ Department of Applied Statistics, East West University, Dhaka, Bangladesh

${ }^{3}$ Drug Analysis and Research Laboratory, Centre for Advanced Research in Sciences (CARS), University of Dhaka, Bangladesh

${ }^{4}$ Department of Biochemistry and Molecular Biology, Tejgaon College, Dhaka, Bangladesh

"Corresponding author: Shozib HB, Grain Quality and Nutrition Division, Bangladesh Rice Research Institute (BRRI), Gazipur- 1701, Bangladesh, Tel: +8801924745991; E-mail: shozib11@gmail.com

Received date: January 31, 2018; Accepted date: February 08, 2018; Published date: February 15, 2018

Copyright: $\odot 2018$ Shozib HB, et al. This is an open-access article distributed under the terms of the Creative Commons Attribution License, which permits unrestricted use, distribution, and reproduction in any medium, provided the original author and source are credited.

\begin{abstract}
Rice is relatively a better source of vitamins, minerals, protein and starch among cereals. In order to identify nutraceutically enriched HYV rice, a total of 35 BRRI released HYVs were subjected to analyze water soluble vitamins such thiamin and riboflavin along with physicochemical and cooking properties. In addition, some profound vitamin enriched HYVs were further subjected to analyze for mineral content such as zinc, iron, phytic acid (PA) and molar ratio of PA to minerals and these were evaluated over variation of degree of milling (DOM) and polishing time

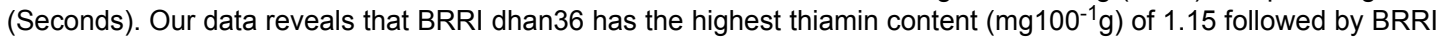
dhan29 (1.14), BRRI dhan48 (1.12), BRRI dhan28 (1.09) and BRRI dhan43 (1.08), BR16 (1.09), BR25 (0.93), BRRI dhan38 (0.93), BRRI dhan64 (0.89) and BRRI dhan42 (0.85) among all tested 35 BRRI HYVs in Bangladesh. Both BRRI dhan43 and BRRI dhan42 have higher Zn content (ppm) of 27.17 and 27.12 among all tested BRRI HYVs rice varieties at $10 \%$ DOM. In addition, we have also observed that grain size and shape have significant impact on degree of milling (DOM) and mineral content trends to be decreased significantly over increasing the polishing time. Considering all nutritional values such as water-soluble vitamins specially thiamin, protein, apparent amylose content, cooking time, elongation ratio, imbibition's ratio, mineral contents such as $\mathrm{Zn}$, Fe, PA and molar ratio of PA to minerals into account, BRRI dhan43 followed by BRRI dhan42 found suitable to treat as nutriceutically enriched HYV rice in Bangladesh among all tested HYVs. Consuming both BRRI dhan43 and BRRI dhan42 as nutraceutically enriched rice alternately, might impact on nutritionally challenged vulnerable portion of Bangladeshi population specially women and children under five years of age.
\end{abstract}

Keywords: Thiamin; Riboflavin; Degree of milling; Polishing time

\section{Introduction}

Rice is consumed as the whole kernel of the white rice which is obtained after milling of the rough rice. The principle of rice milling is the removal of the husk (husking) followed by the rice bran (polishing), which gives us the edible portion (endosperm) of rice grain [1]. Rice bran layer is rich in minerals, vitamins, fat and dietary fibers $[2,3]$, while proteins and fats are concentrated in the germ of the rice caryopsis [4]. Certain nutrients like fats, vitamins, proteins and minerals are found in good concentration in germ and outer layers of endosperm i.e. bran portion of kernels [5]. A study by Lamberts et al. showed that about $84.2 \%$ of kernel proteins are concentrated in outer endosperm and upon milling further the concentration of proteins decrease [6]. The researchers also found that $61 \%$ of most of the minerals are present in bran fraction of the kernels whereas the core of endosperm fraction mainly consists of starch (84.6\%) in the kernels. Milling is a phenomenon of wear which involves removing material from solid surface either by mechanical action or by combinations of various actions such as rolling, impact or sliding [7,8]. Commercial milling is a process consisting of various stages where firstly paddy or rough rice go through dehusking process and then the outer brown bran layer is removed during whitening process. In the final step, adhering bran is completely removed from grain surface and is known as polishing. Quality of milled rice is depicted by two important parameters i.e., whiteness of the kernel and yield of head rice (HRY). Rice can be milled by two methods i.e., abrasion milling and friction milling. When the rice grain is made to revolve inside a milling chamber, then the grain which get in touch with the emery surface experience abrasion type of milling while grain which rub against each other experience adhesive type of wear. In rice polishing, generally a combination of both the types of wear is used as no pure form of milling has yet been discovered [9]. Rubber rolls were determined to be most suitable for laboratory scale milling operations as these increased the dehusking percentage but decreased breakage of rice kernels [10]. During milling operations, these nutrients are removed thus reducing the nutritive value of starch. The degree of milling (DOM) has an effect on the concentration of nutrients. The proximate composition depends upon the degree to which bran has been removed from kernel surface. The rice subjected to lower DOM could lead to more nutrition which can assure better health of the consumers. Minerals are generally concentrated in bran layers of rice kernels which are lost during milling process [11]. It was observed that rice husking parameters are dependent on size and shape of rice kernels and the speed of the impeller cannot be taken as a sole criterion for optimization of impeller husker performance [12]. This could be judged by low husked ratio even if the impeller speed was at its optimum. The quality of rice milling is affected by moisture content of paddy as well as rotor speed of the whitener [13]. Various experiments were performed using different cultivars and different types of milling material such as plywood, iron sheet, rubber, glass and 
fiberglass. Milling against rubber was found to be most effective for paddy but least for milled rice. In another study by Firouzi et al. [14] performance of perforated screen size and blade rotor clearance for whitening of rice grain was evaluated. During milling process, the losses of minerals reached up to $84.7 \%$ [15]. In a study by Fukai et al. different brown rice cultivar was milled and loss in iron content was measured. It was observed that due to milling processes, $25-84 \%$ of iron content was lost from different cultivars [16]. Like other nutrients, selenium was also lost during milling. This observation was based on milling and analysis of 10 different rice cultivars by Liu et al. [15] People take thiamin $\mathrm{VitB}_{1}$ for conditions related to low levels of thiamin (thiamin deficiency syndromes), including beriberi, inflammation of the nerves (neuritis) associated with pellagra or pregnancy. Thiamin is also used for digestive problems including poor appetite, ulcerative colitis, diabetic pain, heart disease, alcoholism, aging, vision problems such as cataracts, glaucoma, motion sickness, improving athletic performance, preventing cervical cancer and progression of kidney disease in patients with type 2 diabetes, AIDS and boosting the immune system. Thiamin functions as a coenzyme in the metabolism of carbohydrates and branched-chain amino acids. Recommended Dietary Allowance (RDA) for adults is 1.2 mgday $^{-1}$ for men and 1.1 mgday-1 for women. Riboflavin functions as a coenzyme in numerous redox reactions. The RDA for riboflavin for adults is 1.3 mgday- 1 for men and 1.1 mgday-1 for women. The redox reactions in which flavocoenzymes participate include flavoprotein-catalyzed dehydrogenations that are both pyridine nucleotide (niacin) dependent and independent, reactions with sulfur-containing compounds, hydroxylations, oxidative decarboxylations (involving thiamin as its pyrophosphate), dioxygenations, and reduction of oxygen to hydrogen peroxide. There are obligatory roles of flavocoenzymes in the formation of some vitamins and their coenzymes. For example, the biosynthesis of two niacin-containing coenzymes from tryptophan occurs via FAD-dependent kynurenine hydroxylase, an FMNdependent oxidase catalyzes the conversion of the 5 -phosphates of viltamin $\mathrm{B}_{6}$ to coenzymic pyridoxal 5'-phosphate, and an FADdependent dehydrogenase reduces 5,10-methylene-tetrahydrofolate to the 5 -methyl product that interfaces with the $B_{12}$-dependent formation of methionine from homocysteine and thus with sulfur amino acid metabolism [17]. Since rice is a good source of water soluble vitamins such as Thiamin $\mathrm{Vit}_{1}$ but poor source of Riboflavin $\mathrm{VitB}_{2}$ and we do not have any prior reports on vitamin profiling of HYVs in Bangladesh till date, so in this experiment we were aimed to explore $\mathrm{VitB}_{1}$ and $\mathrm{VitB}_{2}$ contents for our 35 BRRI HYVs in Bangladesh including their physicochemical and mineral profiling for superior selected BRRI HYVs. In addition, we also tried to explain how the variation of degree of milling (DOM) might possibly affect the mineral contents of rice.

\section{Materials and Methods}

A total of thirty five (35) BRRI HYVs such as BR3, BR5, BR6, BR7, BR10, BR11, BR14, BR16, BR17, BR18, BR19, BR21, BR22, BR23, BR25, BR26, BRRI dhan28, BRRI dhan29, BRRI dhan31, BRRI dhan34, BRRI dhan36, BRRI dhan37, BRRI dhan38, BRRI dhan39, BRRI dhan40, BRRI dhan41, BRRI dhan42, BRRI dhan43, BRRI dhan46, BRRI dhan47, BRRI dhan48, BRRI dhan49, BRRI dhan58, BRRI dhan61 and BRRI dhan64 were selected in this study to evaluate their mineral profiling including zinc, iron, phytic acid and molar ratio of phytate to respective minerals (PA/Zn and $\mathrm{PA} / \mathrm{Fe})$. Rice grain were collected from Genetic Resources and Seed (GRS) Division bank of Bangladesh Rice Research Institute (BRRI) and processed milling at cleaned rice (by $80 \mathrm{sec}$. polishing time) condition for vitamin analysis. Rice samples were dehusked by Satake Rice mill, followed by 80,100 , $120,140,160$ and 180 second polishing in a Grainman rice polisher (USA) to get $8.5 \%, 9.0 \%, 9.5 \%, 9.9 \%, 10.3 \%$ and $10.6 \%$ polished rice (Clean rice) respectively as an average scale for $5 \mathrm{HYVs}$ such as BR25, BRRI dhan36, BRRI dhan42, BRRI dhan 43 and BRRI dhan64 in mineral analysis. All physical parameters were measured following IRRI evaluation standard SES [18]. AAC was determined by the procedure of Juliano [19] and Protein contents were calculated from nitrogen (multiplied by 5.95 factor) and was determined by Micro Kjeldahl method. Volumes of cooked and milled rice were measured by water displacement method. Five grams of milled rice was placed in a graduated cylinder containing $50 \mathrm{~mL}$ of water and the change in volume was noted. For cooked rice volume $5 \mathrm{~g}$ of milled rice was cooked and the cooked rice was placed in the same cylinder and the change in volume was measured. Cooking time was measured when $100 \%$ of cooked rice totally gelatinized. Duncan's multiple range test (DMRT) was applied on DOM\% and Zn content of five selected HYVs which varied over 80 seconds to 180 seconds of polishing for statistical analysis using SPSS, version 20.0 .

\section{Determination of thiamin and riboflavin}

These water-soluble vitamins are extracted from the rice powder by acid hydrolysis followed by enzymatic hydrolysis. The aqueous extract is injected onto a reverse phase HPLC column. The fluorescence of riboflavin is measured, and thiamin is determined after post column derivatisation with alkaline potassium ferricyanide that converts the thiamin to thiochrome [20-24]. The method is described for the determination of thiamin and riboflavin in rice by HPLC in ASEAN Manual of Food Analysis [25].

Estimation of iron and zinc: Sample were digested and estimated by the method of the Association of Official Agricultural Chemists [26]. About $0.5 \mathrm{~g}$ rice powder was taken into a $25 \mathrm{~mL}$ conical flask and then for extraction of minerals, $5 \mathrm{~mL}$ mixture of nitric acid: perchloric acid (5:2) was added to the flask. The sample were heated at $350^{\circ} \mathrm{C}$ for digestion until the color became clear. Then the digested sample were cooled and filtered through a Whatman filter paper No. 1 and the volume was made up to $25 \mathrm{~mL}$ with de-ionized distilled water (Branstad, USA). Iron, zinc and calcium were determined by the atomic absorption spectrometry (Shimadzu Atomic Absorption Spectrophotometer AA-6800) using a different standard curve for each. For the preparation of standard curve for iron, absorbance of 0.0 , $1.0,2.0,4.0,8.0 \mu \mathrm{g} \mathrm{mL}^{-1}$ iron solutions at $348.3 \mathrm{~nm}$ and for zinc 0.05 , $0.100 .20,0.40,0.80,1.00 \mu \mathrm{g} \mathrm{mL}^{-1}$ at $213.8 \mathrm{~nm}$ were taken respectively.

Estimation of Phytic Acid (PA): Phytic acid present in rice samples were determined colorimetrically by Wheeler and Ferral method [27]. About $200 \mathrm{mg}$ rice powder was weighed and transferred into a $15 \mathrm{~mL}$ centrifuge tube. Then $7.5 \mathrm{~mL}$ TCA (5\%) solution was added and vortexed the mixture. The mixture was incubated at $60^{\circ} \mathrm{C}$ for 10 minutes and then centrifuged at $5000 \mathrm{rpm}$ for 10 minutes. The supernatant was transferred into a $25 \mathrm{~mL}$ volumetric flask. The extraction was repeated for 2 more times and transferred the supernatant into the volumetric flask and the volume was made up to $25 \mathrm{~mL}$. Twenty $\mathrm{mL}$ extracted sample was taken into a $75 \mathrm{~mL}$ Technicon tube and then $5 \mathrm{~mL}$ ferric chloride solution was added. The tubes were then heated in a block digestor at $95^{\circ} \mathrm{C}$ for 45 minutes. After cooling the tube, it was made up to $75 \mathrm{~mL}$ with deionized water and filtered through Whatman filter paper No. 42. Pipetted out $2.5 \mathrm{~mL}$ filtrates and then $2 \mathrm{~mL}$ potassium thiocyanate $(29 \%)$ and $5 \mathrm{~mL}$ de-ionized water 
Page 3 of 6

was added in each of the tube for making total volume $9 \mathrm{~mL}$. Then after mixing, the absorbance of the mixture was measured at $485 \mathrm{~nm}$ against water as blank. Pipetted out $5 \mathrm{~mL}$ of ferric chloride solution into a tube, and then $20 \mathrm{~mL}$ de-ionized water and $2 \mathrm{~mL}$ TCA (5\%) was added. The flask was heated in a block digestor at $95^{\circ} \mathrm{C}$ for 45 minutes. After cooling the tube, it was made up to $75 \mathrm{~mL}$ with de-ionized water and filtered through Whatman filter paper No. 42. Then filtrates were pipetted from 0.5 to $2.5 \mathrm{~mL}$ in different tubes. The volume was made up to $7.5 \mathrm{~mL}$ with de-ionized water and $2 \mathrm{~mL}$ of potassium thiocynate (29\%) was added in each tube. After mixing, the absorbance of the solution was measured at $485 \mathrm{~nm}$. A standard graph of ferric ion was plotted. From the graph, the slope was determined and then values for phytic acid was calculated on the assumption that four ferric ions combine with one molecule of phytic acid $\left(\mathrm{Fe}_{4} \mathrm{P}_{6} \mathrm{C}_{6} \mathrm{H}_{6} \mathrm{O}_{24}\right)$. Calculation was done on the basis of dry weight of the sample.

Molar ratio of phytic acid (PA) to $\mathrm{Zn}$ and Fe: The molar ratio of $\mathrm{PA} / \mathrm{Zn}$ and $\mathrm{PA} / \mathrm{Fe}$ were calculated as follows; the molar intake of phytate (molecular weight, 660) was divided by the molar intake of $\mathrm{Zn}$ (molecular weight, 65) and molar intake of Fe (molecular weight, 56) respectively.

\section{Results and Discussion}

In this study protein content of BRRI HYVs were found averagely at $8.1 \pm 1.0 \%$ along with a range from $6.4 \%-10.4 \%$. According to HIES BBS, 2016 data of Bangladesh, per capita rice consumption is 367 (g capita $^{-1}$ day $\left.^{-1}\right)$. Considering the amount in to account, we are getting approximately $29.73 \mathrm{~g}\left(8.1^{\star} 367 / 100 \mathrm{~g}\right)$ of protein from rice daily where RDA of protein is $56 \mathrm{~g}$ for an average $70 \mathrm{Kg}$ (Recommended amount is $0.8 \mathrm{~g}$ protein intake $\mathrm{kg}^{-1}$ body weight day-1) weighted individual of Bangladeshi population. BRRI dhan34, BRRI dhan36 and BRRI dhan 37 possess more than $10 \%$ of protein at brown rice condition. Apparent amylose content (AAC) is very important characteristic for varietal characterization and development. Since Bangladeshi population usually prefers non-sticky rice over sticky rice. Even through, there is no single trait responsible for significant correlation between AAC and stickiness of rice but others such as alpha amylase inhibitor, degree of milling etc. BRRI usually prefers to release advance lines whose AAC is preferably higher than $25 \%$ and it found at a range from $20-27 \%$ of ACC (Table 1). BRRI dhan 43 and BRRI dhan 42 has relatively high AAC value of 26.7 and $26.1 \%$ respectively.

\begin{tabular}{|l|l|l|l|l|l|}
\hline Variety & Protein & AAC & $\begin{array}{l}\text { Cooking } \\
\text { Time }\end{array}$ & ER & IR \\
\hline BRRI HYV rice & $\mathbf{( \% )}$ & $\mathbf{( \% )}$ & $\mathbf{( M i n . )}$ & Ratio & Ratio \\
\hline BR3 & 8.1 & 26.2 & 17 & 1.4 & 3.4 \\
\hline BR5 & 9.0 & 26.0 & 14 & 1.6 & 3.4 \\
\hline BR6 & 7.1 & 26.0 & 17 & 1.4 & 3.6 \\
\hline BR7 & 8.1 & 22.3 & 16 & 1.3 & 3.5 \\
\hline BR10 & 8.3 & 26.0 & 16 & 1.3 & 3.7 \\
\hline BR11 & 8.2 & 26.0 & 17 & 1.4 & 3.6 \\
\hline BR14 & 7.5 & 27.1 & 18 & 1.4 & 3.6 \\
\hline BR16 & 7.4 & 27.0 & 18 & 1.4 & 3.5 \\
\hline BR17 & 7.0 & 27.0 & 20 & 1.4 & 3.7 \\
\hline
\end{tabular}

\begin{tabular}{|c|c|c|c|c|c|}
\hline BR18 & 8.2 & 27.0 & 21.0 & 1.3 & 3.7 \\
\hline BR19 & 7.5 & 26.2 & 18.0 & 1.3 & 3.6 \\
\hline BR21 & 8.8 & 25.1 & 15.0 & 1.4 & 3.4 \\
\hline BR22 & 7.3 & 26.0 & 18.0 & 1.5 & 3.8 \\
\hline BR23 & 7.8 & 27.2 & 17.0 & 1.4 & 3.4 \\
\hline BR25 & 9.1 & 25.9 & 19.0 & 1.4 & 4 \\
\hline BR26 & 8.4 & 22.6 & 19.5 & 1.3 & 4.1 \\
\hline BRRI dhan28 & 8.7 & 26.5 & 17.5 & 1.5 & 4.3 \\
\hline BRRI dhan29 & 7.0 & 27.0 & 18.5 & 1.4 & 4.4 \\
\hline BRRI dhan31 & 8.9 & 26.5 & 20.5 & 1.4 & 4 \\
\hline BRRI dhan34 & 10.2 & 23.0 & 13.0 & 1.4 & 4 \\
\hline BRRI dhan36 & 10.1 & 25.4 & 19.0 & 1.3 & 3.7 \\
\hline BRRI dhan37 & 10.4 & 23.8 & 20.0 & 1.2 & 3.7 \\
\hline BRRI dhan38 & 8.8 & 22.6 & 19.0 & 1.3 & 3.7 \\
\hline BRRI dhan39 & 8.4 & 26.6 & 19.5 & 1.3 & 3.7 \\
\hline BRRI dhan40 & 7.6 & 25.7 & 19.0 & 1.4 & 4 \\
\hline BRRI dhan41 & 6.4 & 24.6 & 17.5 & 1.4 & 4 \\
\hline BRRI dhan42 & 8.4 & 26.1 & 18.5 & 1.4 & 4.3 \\
\hline BRRI dhan43 & 7.5 & 26.7 & 15.5 & 1.4 & 4.4 \\
\hline BRRI dhan46 & 8.2 & 24.7 & 16.3 & 1.4 & 3.3 \\
\hline BRRI dhan47 & 6.6 & 26.1 & 22.0 & 1.4 & 3.6 \\
\hline BRRI dhan48 & 8.0 & 26.8 & 18.3 & 1.4 & 3.4 \\
\hline BRRI dhan49 & 8.7 & 24.8 & 20.0 & 1.4 & 3.6 \\
\hline BRRI dhan58 & 7.2 & 26.0 & 15.4 & 1.3 & 3 \\
\hline BRRI dhan61 & 7.1 & 20.0 & 16.0 & 1.3 & 3.5 \\
\hline BRRI dhan64 & 7.4 & 23.0 & 22.0 & 1.4 & 3.1 \\
\hline Mean \pm STD & $8.1 \pm 1.0$ & $25.4 \pm 1.7$ & $17.9 \pm 2.1$ & $1.4 \pm 0.1$ & $3.7 \pm 0.3$ \\
\hline Range & $6.4-10.4$ & $20.0-27.0$ & $13.0-22.0$ & $1.2-1.6$ & $3.0-4.4$ \\
\hline
\end{tabular}

Table 1: Chemical and cooking properties of 35 BRRI HYVs.

\begin{tabular}{|c|c|c|}
\hline BRRI HYV rice & Thiamin $\mathrm{mg}^{100^{-1} \mathrm{~g}}$ & Riboflavin $\mathrm{mg}^{100^{-1} \mathrm{~g}}$ \\
\hline BR 3 & 0.46 & 0.056 \\
\hline BR 5 & 0.8 & 0.071 \\
\hline BR 6 & 0.56 & 0.019 \\
\hline BR 7 & 0.4 & 0.008 \\
\hline BR 10 & 0.55 & 0.069 \\
\hline BR 11 & 0.51 & 0.042 \\
\hline BR 14 & 0.59 & 0.095 \\
\hline
\end{tabular}




\begin{tabular}{|c|c|c|}
\hline BR 16 & 1.05 & 0.075 \\
\hline BR 17 & 0.45 & 0.039 \\
\hline BR 18 & 0.67 & 0.06 \\
\hline BR 19 & 0.62 & 0.045 \\
\hline BR 21 & 0.45 & 0.011 \\
\hline BR 22 & 0.82 & 0.032 \\
\hline BR 23 & 0.83 & 0.014 \\
\hline BR25 & 0.93 & 0.08 \\
\hline BR 26 & 0.53 & 0.002 \\
\hline BRRI dhan28 & 1.09 & 0.045 \\
\hline BRRI dhan29 & 1.14 & 0.047 \\
\hline BRRI dhan31 & 0.84 & 0.044 \\
\hline BRRI dhan34 & 0.79 & 0.038 \\
\hline BRRI dhan36 & 1.15 & 0.019 \\
\hline BRRI dhan37 & 0.83 & 0.057 \\
\hline BRRI dhan38 & 0.93 & 0.08 \\
\hline BRRI dhan39 & 0.58 & 0.017 \\
\hline BRRI dhan40 & 0.83 & 0.058 \\
\hline BRRI dhan41 & 0.78 & 0.048 \\
\hline BRRI dhan42 & 0.85 & 0.03 \\
\hline BRRI dhan43 & 1.08 & 0.064 \\
\hline BRRI dhan46 & 0.75 & 0.016 \\
\hline BRRI dhan47 & 0.73 & 0.03 \\
\hline BRRI dhan48 & 1.12 & 0.023 \\
\hline BRRI dhan49 & 0.84 & 0.025 \\
\hline BRRI dhan58 & 1.09 & 0.046 \\
\hline BRRI dhan61 & 0.82 & 0.026 \\
\hline BRRI dhan64 & 0.89 & 0.045 \\
\hline Mean \pm STD & $0.78 \pm 0.22$ & $0.042 \pm 0.023$ \\
\hline Ranges & $0.41-1.15$ & $0.002-0.095$ \\
\hline
\end{tabular}

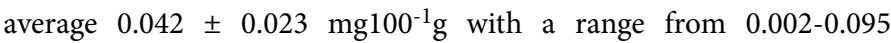
$\mathrm{mg} 100^{-1} \mathrm{~g}$ at $(8.0 \pm 0.50 \%$ polished $)$ milled rice. We can get approximately $0.15 \mathrm{mg}(0.042 * 367 / 100 \mathrm{mg})$ of thiamin from rice daily where RDA of riboflavin for adults is 1.3 mgday $^{-1}$ for men and 1.1 mgday $^{-1}$ for women [28]. So, it seems rice is not a good source of riboflavin but BR14 showed the highest amount of riboflavin content

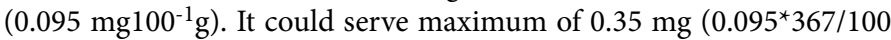
$\mathrm{mg}$ ) riboflavin daily (Table 2 ).

Selective mineral profiling of BRRI HYVs were analyzed and the selection criteria was set at the level of Thiamin $\mathrm{VitB}_{1}$ is $\geq 0.85$ mg $100^{-1} \mathrm{~g}$ (Tables 2 and 3). Phytic Acid (PA) and molar ratio of PA to minerals ( $\mathrm{Zn}$ and $\mathrm{Fe}$ ) were also selectively analyzed and the selection criteria was set at the level of $\mathrm{Zn}$ is $\geq 20 \mathrm{ppm}$. In this regard, a total of 10 BRRI HYVs were subjected analyzed for mineral profiling such as $\mathrm{Zn}$ and Fe content and among them only 5 BRRI HYVs were also subjected to further analyzed for PA and molar ratio of PA to minerals ( $\mathrm{Zn}$ and $\mathrm{Fe}$ ). All mineral data are assembled in a tabular form in table 3 where DOM was approximately $(10.2 \pm 0.22 \%)$.

\begin{tabular}{|l|l|l|l|l|l|l|}
\hline Variety & & Zn & Fe & PA & PA/Zn & PA/Fe \\
\hline $\begin{array}{l}\text { BRRI } \\
\text { HYV rice }\end{array}$ & DOM\% & (ppm) & (ppm) & (mg/g) & (Ratio) & (Ratio) \\
\hline BR 16 & 10.2 & 16.49 & 5.16 & ND & ND & ND \\
\hline BR25 & 10.12 & 21.3 & 4.54 & 19 & 9 & 43 \\
\hline $\begin{array}{l}\text { BRRI } \\
\text { dhan28 }\end{array}$ & 10.43 & 15.21 & 8.17 & ND & ND & ND \\
\hline $\begin{array}{l}\text { BRRI } \\
\text { dhan29 }\end{array}$ & 10.3 & 16.02 & 7.78 & ND & ND & ND \\
\hline $\begin{array}{l}\text { BRRI } \\
\text { dhan36 }\end{array}$ & 10.38 & 20.43 & 10.12 & 15 & 6 & 13 \\
\hline $\begin{array}{l}\text { BRRI } \\
\text { dhan38 }\end{array}$ & 10.11 & 10.19 & 20.32 & ND & ND & ND \\
\hline $\begin{array}{l}\text { BRRI } \\
\text { dhan42 }\end{array}$ & 10.46 & 27.12 & 4.13 & 14 & 5 & 23 \\
\hline $\begin{array}{l}\text { BRRI } \\
\text { dhan43 }\end{array}$ & 10.43 & 27.17 & 10.09 & 14 & 3 & 4 \\
\hline $\begin{array}{l}\text { BRRI } \\
\text { dhan48 }\end{array}$ & 9.56 & 11.3 & 9.11 & ND & ND & ND \\
\hline $\begin{array}{l}\text { BRRI } \\
\text { dhan64 }\end{array}$ & 10.15 & 20.1 & 11.21 & 24 & 10 & 18 \\
\hline $\begin{array}{l}\text { Mineral profiling of selected BRRI HYVs which Thiamin (VitB1) level is } \geq 0.85 \\
\text { mg100-1 g. Phytic Acid (PA) and molar ratio PA to minerals (Zn and Fe) were } \\
\text { analyzed for BRRI HYVs which Zn level } \geq 20 \text { ppm. ND=Not Done. }\end{array}$ \\
\hline
\end{tabular}

Table 2: Water soluble vitamins (Thiamin and Riboflavin) profiling of 35 BRRI HYVs.

If we consider average thiamin content of $0.78 \pm 0.22 \mathrm{mg} 100^{-1} \mathrm{~g}$ into account, then we will get $2.87 \mathrm{mg}\left(0.781^{\star} 367 / 100 \mathrm{mg}\right)$ of thiamin daily from rice intake only (Table 2 ). The median intake of thiamin from food in the United States is approximately 2 mgday $^{-1}$, and the ninetyfifth percentile of intake from both food and supplements was approximately $6.1 \mathrm{mgday}^{-1}$. Since thiamin is a water soluble vitamin so tolerable upper intake level UL for thiamin is not fixed yet [27] but deficiency is scared. Our BRRI HYVs rice are found very good source of thiamin. Regarding riboflavin, BRRI HYVs possess riboflavin at

Table 3: Mineral profiling of 10 selected BRRI HYVs (DOM at $10.20 \pm$ $0.22 \%)$.

Zn content of both BRRI dhan43 (27.17 ppm) followed by BRRI dhan42 (27.12 ppm) were found higher in this study even at $(10.20 \pm$ $0.22) \%$ DOM. Earlier in 2017, Shozib et al. [29] reported mineral profiling of 68 BRRI HYVs in Bangladesh but $\mathrm{Zn}$ content varied for these reported varieties because of variation of DOM percentage. Eighty ( 80 Seconds) of polishing by Gainman polisher was applied for all tested varieties which gave around $8.5 \%$ of DOM as an average. Grain size and shape also has a role in DOM, so we tried to explore the explanation of zinc content variation over increasing DOM. Our data 
Page 5 of 6

reveals that mineral content specially $\mathrm{Zn}$ content varied over increasing DOM and polishing time (Figure 1 and Table 4).

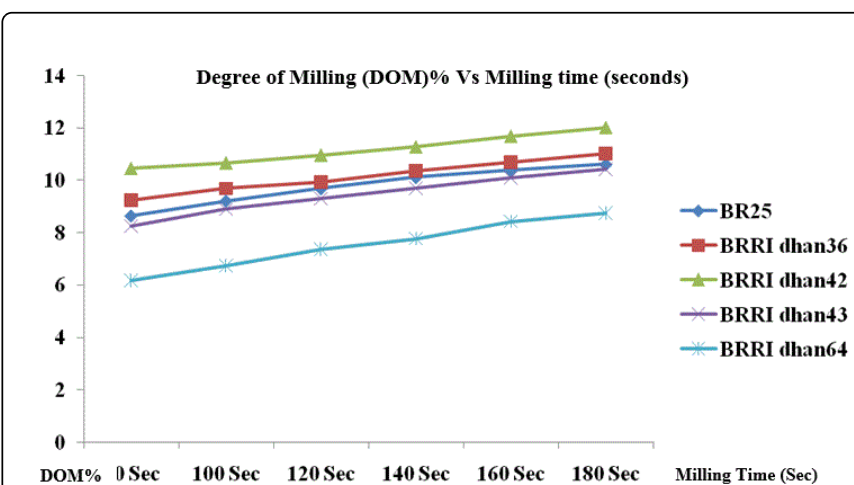

Figure 1: Varietal differences of Degree of Milling (DOM\%) over polishing time ( $80 \mathrm{Sec}-180 \mathrm{Sec}$ at Grainman rice polisher).

\begin{tabular}{|c|c|c|c|c|c|c|}
\hline HYVs & $\begin{array}{l}\mathrm{L} \\
\text { (mm }\end{array}$ & $\begin{array}{l}\mathrm{L} / \mathrm{B} \\
\text { ratio }\end{array}$ & S\&S & $\begin{array}{l}\text { DOM\% } \\
\text { at } \\
80 \mathrm{Sec}\end{array}$ & $\begin{array}{l}\text { DOM\% at } \\
140 \mathrm{Sec}\end{array}$ & $\begin{array}{l}\text { DOM\% at } \\
180 \mathrm{Sec}\end{array}$ \\
\hline BR25 & 4.7 & 2.6 & SB & $8.65^{a}$ & $10.12^{\mathrm{a}}$ & $10.62^{\mathrm{a}}$ \\
\hline BRRI dhan 36 & 6.1 & 3.2 & LS & $9.24^{b}$ & $10.38^{b}$ & $11.04^{b}$ \\
\hline BRRI dhan42 & 6.5 & 3.1 & LS & $10.46^{c}$ & $11.28^{c}$ & $12.02^{c}$ \\
\hline BRRI dhan43 & 5.8 & 2.4 & $\mathrm{MB}$ & $8.25^{d}$ & $9.30^{d}$ & $10.43^{d}$ \\
\hline BRRI dhan64 & 5.3 & 2.1 & MB & $6.19^{\mathrm{e}}$ & $7.78^{\mathrm{e}}$ & $10.15^{\mathrm{e}}$ \\
\hline \multicolumn{7}{|c|}{$\begin{array}{l}\text { L: Length; L/B ratio: Length /Breadth ration of polish rice; S\&S: Size and Shape; } \\
\text { SM; Small and Medium; LS; Long and Slender; MB; Medium and Bold; DOM: } \\
\text { Degree of milling; ppm: } \mathrm{mgkg}^{-1} \text {. Any two-means having common letter (s) are } \\
\text { not statistically different at a } \mathrm{P}<0.05 \text {, as measured by the Duncan Multiple } \\
\text { Range Test (DMRT). }\end{array}$} \\
\hline
\end{tabular}

Table 4: Variation of DOM\% of 5 HYVs at different time points (80 sec, 140 secs and $180 \mathrm{sec}$ ).

\begin{tabular}{|l|l|l|l|l|l|}
\hline HYVs & BR25 & BRRI dhan36 & BRRI dhan42 & BRRI dhan43 & BRRI dhan64 \\
\hline Polishing time at $80 \mathrm{Sec}$ & $24.70^{\mathrm{a}}$ & $23.6^{\mathrm{a}}$ & $27.12^{\mathrm{a}}$ & $38.40^{\mathrm{a}}$ & $24.46^{\mathrm{a}}$ \\
\hline Polishing time at $140 \mathrm{Sec}$ & $21.30^{\mathrm{b}}$ & $20.43^{\mathrm{b}}$ & $24.21^{\mathrm{b}}$ & $32.90^{\mathrm{b}}$ & $22.10^{\mathrm{b}}$ \\
\hline Polishing time at $180 \mathrm{Sec}$ & $18.21^{\mathrm{c}}$ & $17.34^{\mathrm{c}}$ & $20.43^{\mathrm{c}}$ & $27.17^{\mathrm{c}}$ & $20.10^{\mathrm{c}}$ \\
\hline
\end{tabular}

Table 5: Variation of $\mathrm{Zn}$ content (ppm or $\mathrm{mgKg}^{-1}$ ) of $5 \mathrm{HYVs}$ at different time points (80, 140, and $180 \mathrm{sec}$ ).

Lamberts et al. in 2007 [30] reported that the mineral content is the highest in bran (61.0\%), followed by outer endosperm (23.7\%), core endosperm (11.6\%), and the lowest in the middle endosperm $(3.7 \%)$. Proteins, minerals and starch were not uniformly distributed in the brown rice kernel. Bran $(0 \%<\mathrm{DOM}<9 \%)$ contained most of the minerals (61.0\%). In our experiment we found variation in $\mathrm{Zn}$ content with increasing polishing time from 80 seconds to 180 seconds and DOM (Table 4). At 80 seconds of polishing, DOM varied ranges from 6.19 to $10.46 \%$ for five selected HYVs whose grain size and shape are also varied from small and medium grain, long and slender grain, medium and bold grain etc. Zn content of BR25, BRRI dhan36, BRRI dhan42, BRRI dhan 43 and BRRI dhan64 were $24.70 \mathrm{ppm}, 23.60 \mathrm{ppm}$, $27.12 \mathrm{ppm}, 38.40 \mathrm{ppm}$ and $24.46 \mathrm{ppm}$ at 80 seconds of polishing. $\mathrm{Zn}$ content of BR25, BRRI dhan36, BRRI dhan 42 , BRRI dhan 43 and BRRI dhan64 were $21.30 \mathrm{ppm}, 20.43 \mathrm{ppm}, 24.21 \mathrm{ppm}, 32.90 \mathrm{ppm}$ and 22.10 $\mathrm{ppm}$ at 140 seconds of polishing where DOM varied ranges from 7.78 to $11.28 \%$. Finally, Zn content of BR25, BRRI dhan36, BRRI dhan42, BRRI dhan 43 and BRRI dhan64 were $18.21 \mathrm{ppm}, 17.34 \mathrm{ppm}, 20.43$ ppm, $27.17 \mathrm{ppm}$ and $20.10 \mathrm{ppm}$ at 180 seconds of polishing where DOM varied ranges from 10.15 to $12.02 \%$ (Tables 4 and 5). We have clearly demonstrated how $\mathrm{Zn}$ content and DOM\% of 5 different BRRI HYVs significantly varied at different polishing time ranges from 80 seconds to 180 seconds (Tables 4 and 5) considering grain size and shape into account.

Indica type Bangladeshi HYVs are seems very rich in vitamins, minerals, protein and starch content. In this study we were aiming to identify few nutraceutically enriched HYVs which may be rich in vitamins, minerals along with superior physicochemical and cooking properties. Considering all nutritional values such as water-soluble vitamins specially thiamin, protein, apparent amylose content, cooking time, elongation ratio, imbibition's ratio, mineral contents such as Zn, $\mathrm{Fe}, \mathrm{PA}$ and molar ratio of PA to minerals into account, we found few BRRI HYVs which are appropriate to treat as nutriceutically enriched HYV rice in Bangladesh. In addition, higher content of minerals in rice can only be attained at lower degree of polishing $(<10 \% \mathrm{DOM})$ and grain size and shape can equally be important trait in considering DOM of individual rice genotypes. Naturally selected these nutraceutically enriched HYVs can possibly play a pivotal role in attaining better nutrition through widely consume rice at 367 (g capita $^{-1}$ day $^{-1}$ ) in Bangladesh at present fashion.

\section{Conclusion}

In conclusion, we would like to emphasis some promising HYVs such as BRRI dhan 43 and BRRI dhan 42 since these HYVs have relatively higher concentration of thiamin $\left(\geq 0.85 \mathrm{mg}^{-100^{-1}}\right)$, zinc $(\geq$ $27.0 \mathrm{ppm})$, apparent amylose content $(\geq 27 \%)$, imbibitions ratio $(\geq 4.3)$ and lower content of phytic acid $\left(\leq 14 \mathrm{mgg}^{-1}\right)$ and molar ratio of PA to minerals among all tested BRRI HYVs in Bangladesh. Since, lower degree of milling is associated with higher mineral content, so it is further recommended to consume lower degree of polished rice $(<10 \%$ $\mathrm{DOM})$ rather over polishing $(\geq 10 \%)$. Rice grain size and shape has been found significant impact on degree of milling (DOM) and mineral content trends to be decreased significantly over increasing the polishing time. This acquainted information might be very useful in rice and rice-based food industries in Bangladesh. Further research activities should be conducted in an attempt to assess bioavailability of 
both micronutrients and vitamins of nutraceutically enriched BRRI HYVs specially BRRI dhan 43 and BRRI dhan 42 in human trail.

\section{References}

1. Savitha YS, Singh V (2011) Status of dietary fiber contents in pigmented and non-pigmented rice varieties before and after parboiling. LWT Food Sci Technol 44: 2180-2184.

2. Roy P, Ijiri T, Okadome H, Nei D, Orikasa T, et al. (2008) Effect of processing conditions on overall energy consumption and quality of rice (Oryza sativa L). J Food Engin 89: 343-348.

3. Paiva FF, Vanier NL, Berrios JD, Pinto VZ, Wood D, et al. (2016) Polishing and parboiling effect on the nutritional and technological properties of pigmented rice. Food Chem 191: 105-112.

4. Itani T, Tamaki M, Arai E, Horino T (2002) Distribution of amylose, nitrogen, and minerals in rice kernels with various characters. J Agric Food Chem 50: 5326-5332.

5. Juliano BO (1985) Criteria and Test for Rice Grain Qualities. In: Rice Chemistry and Technology, 2nd edn. American Association of Cereal Chemists: Eagan, MN, USA, pp: 443-517.

6. Lamberts L, Bie LD, Vandeputte GE, Veraverbeke WS, Derycke V (2007) Effect of milling on colour and nutritional properties of rice. Food Chem. 100: 1496-1503.

7. Robinowicz E (1965) Friction and Wear of Materials. Wiley, New York.

8. Sarkar AD (1976) Wear of Metals. Pergamon Press, Oxford.

9. Mohapatra D, Bal S (2006) Cooking quality and instrumental textural attributes of cooked rice for different milling fractions. J Food Engg 73: 253-259.

10. Payman MH, Tavakoli T, Minaei S (1999) Determination of appropriate clearance between rolls in rubber-roll huskers in milling operations of three common rice varieties in Guilan. Iran J Agri Sci 5: 37-48.

11. Shruti P, Bhavnita D, Navdeep SS (2014) Effect of Degree of Milling (Dom) on Overall Quality of Rice - A Review. Int J of Adv Bio Res (IJBR) 5: 474-489.

12. Shitanda D, Nishiyama Y, Koide S (2001) Performance analysis of an impeller husker considering the physical and mechanical properties of paddy rice. J Agri Engg Res 79: 195-203.

13. Yan TY, Hong JH, Chung JH (2005) A prediction of white improved method for the embryo in vertical mill. Biosys Eng 49: 303-309.

14. Firouzi S, Alizadeh MR, Minaei S (2010) Effect of the size of perforated screen and blade-rotor clearance on the performance of Englebreg rice whitener. Afr J Agri Res 5: 941-946.
15. Liu K, Cao X, Bai Q, Wen H, Gu Z (2009) Relationships between physical properties of brown rice and degree of milling and loss of selenium. J Food Eng 94: 69-74.

16. Prom-u-Thai C, Fukai S, Godwin ID, Huang LB (2007) Genotypic variation of iron partitioning in rice grain. J Sci Food Agri 87: 2049-2054.

17. Institute of Medicine (US) Standing Committee on the Scientific Evaluation of Dietary Reference Intakes and its Panel on Folate, Other B Vitamins, and Choline (1998) Dietary Reference Intakes for Thiamin, Riboflavin, Niacin, Vitamin B6, Folate, Vitamin B12, Pantothenic Acid, Biotin, and Choline. National Academies Press, Washington DC, USA.

18. International Rice Research Institute (IRRI) (2013) Standard Evaluation System for Rice. 5th edn. IRRI, Manila, Philippines.

19. Juliano BO (1971) A simplified assay for milled rice amylose. Cereal Sci Today 16: 334-360.

20. Horwitz W (2000) Official Methods of Analysis of AOAC International.

21. Wehling RL, Wetzel DL (1984) Simultaneous determination of pyridoxine, riboflavin, and thiamin in fortified products by highperformance liquid chromatography. J Agric Food Chem 32: 1326-1331.

22. Wimalasiri P, Wills RB (1985) Simultaneous analysis of thiamin and riboflavin in foods by high-performance liquid chromatography. J Chromatography 318: 412-416.

23. Ellefson WC (1985) Methods of Vitamin Assay. In: Augustin J, Klein BP, Beker DA, Venugopal PB (eds.) John Wiley \& Sons, Inc., New York, U.S.A pp: 349-363.

24. Shah JJ (1985) Methods of Vitamin Assay. In: Augustin J, Klein BP, Beker DA, Venugopal PB (eds.) Wiley \& Sons, Inc., New York, U.S.A, pp: 365-383.

25. Prapasri P, Tee ES, Julia K, Graham C, Rafael RF, et al. (2011) J ASEAN Manual of Food Analysis, pp: 103-108.

26. AOAC (1995) Official procedure of mineral estimations ( $\mathrm{Zn}$ and $\mathrm{Fe}$ ) of Association of Official Agricultural Chemists (AOAC).

27. Wheeler EL, Ferrel RE (1971) Phytic acid and phytase activity in four cottonseed protein products. Cereal Chem 52: 665.

28. Titchenal CA (2004) The UL for magnesium represents intake specifically from pharmacological agents and/or dietary supplements in addition to dietary intake. NASM Certified Personal Trainer Course Manual, pp: 632-633.

29. Shozib HB, Jahan S, Das SC, Alam S, Amin RB, et al. (2017) Mineral Profiling of HYV Rice in Bangladesh. Vitam Miner 6: 164.

30. Lamberts L, de Bie E, Vandeputte GE, Veraverbeke WS, Derycke V, et al. (2007) Effect of milling on colour and nutritional properties of rice. Food Chem 100: 1496-1503. 